\title{
Phosphatidylinositol 3-kinase/nuclear factor- $\kappa B$ signaling pathway is involved in the regulation of IGF-I on Fas-associated death domain-like interleukin-1-converting enzyme-inhibitory protein expression in cultured FRTL thyroid cells
}

\author{
Meng Ren, Qingbo Guan ${ }^{1}$, Xia Zhong', Bendi Gong ${ }^{2}$, Ying Sun, Wei Xin, Jun Guo', \\ Hai Wang ${ }^{1}$, Ling Gao and Jiajun Zhao' \\ Central Laboratory, and ${ }^{1}$ Department of Endocrinology of Shandong Provincial Hospital, Shandong University, Jinan 250021, China \\ ${ }^{2}$ Department of Neurology, Case Western Reserve University, Cleveland, Ohio 44106, USA \\ (Requests for offprints should be addressed to J Zhao; Email: jjzhao@ medmail.com.cn) \\ (M Ren and Q B Guan contributed equally to this work)
}

\begin{abstract}
It is known that decreased apoptosis of thyrocytes may be involved in the formation of goiters in patients with Graves' disease, and growth factors are involved in regulating the size of the thyroid gland. The purpose of our study was to investigate mRNA and protein levels of an antiapoptotic protein, namely, Fas-associated death domain-like interleukin-1converting enzyme (FLICE)-inhibitory protein (FLIP). The results showed that in FRTL thyroid cells, treatment with IGF-I upregulated mRNA and protein levels of FLIP in a dose-dependant manner. While a specific nuclear factor- $\kappa B$ (NF- $\kappa B$ ) inhibitor, BAY11-7082, blocked this effect. Further study demonstrated that IGF-I induced the DNA-binding activity of $N F-\kappa B$ in association with decreased expression of the NF- $\kappa B$ inhibitory protein $I \kappa B \alpha$. These findings implied that IGF-I increased FLIP expression by enhancing the activation of NF- $\kappa B$ in FRTL thyroid cells. Using a specific phosphatidylinositol 3-kinase (PI3K) inhibitor, LY294002, we also found that PI3K was involved in the pathway by which IGF-I activated NF- $\kappa$ B and increased FLIP expression. When treated with IGF-I and LY294002, decreased NF- $\kappa B$ DNA binding activity and increased expression of $I \kappa B \alpha$ protein were detected in cultured thyroid cells, which further confirmed that NF- $\kappa B$ was under the control of the PI3K pathway. Taken together, our results suggest that IGF-I regulates the expression of FLIP in FRTL cells by activating the PI3K/NF- $\kappa B$ cascade.
\end{abstract}

Journal of Molecular Endocrinology (2007) 38, 619-625

\section{Introduction}

Thyroid goiter is a main feature of Graves' disease. There are several consequences of goiter, such as compression of airways and so on, which influence the life quality of patients. An imbalance between the proliferation and the apoptosis of thyroid cells may be crucial for goiter formation (Irmler et al. 1997, Ashkenazi \& Dixit 1998). However, the precise mechanism of goitrogenesis in terms of thyrocyte growth regulation is yet to be understood. It has been known that cellular Fasassociating protein with death domain-like interleukin1-converting enzyme (FLICE)-inhibitory protein (FLIP) blocks Fas-induced apoptosis. In Graves' disease, upregulation of FLIP leads to an absence of thyrocyte apoptosis and thyroid goiter (Mitsiades et al. 2001).

Insulin-like growth factor-I (IGF-I) is an important hypertrophic and antiapoptotic factor for a number cell types (Kofidis et al. 2004, Radcliff et al. 2005). It produces its biologic effects by means of the IGF-I receptor, which mediates many of these effects by activating phosphatidylinositol 3-kinases (PI3Ks). In the thyroid, IGF-I collaborates with thyrotropin and stimulates the growth of thyroid cells (Kimura et al. 2001, Saito et al. 2001). In the study of thyroid goiter formation, interest in the role of IGF-I has increased. IGF-I may be important in the pathogenesis of Graves' disease, and it is involved in the formation of thyroid goiter (Maiorano et al. 1998, Miyakawa et al. 2003). Our previous study showed that serum IGF-I levels were positively correlated with thyroid volumes observed in Graves' disease. In thyroid tissues, IGF-I was locally produced and more strongly expressed than in normal thyroid tissue (Zhong et al. 2006). These findings indicated that IGF-I has autocrine and paracrine roles in the formation of thyroid goiters. However, whether IGF-I is correlated with FLIP expression and what the signaling pathways are remain uncertain.

A growing body of evidence demonstrates that nuclear factor- $\kappa \mathrm{B}(\mathrm{NF}-\kappa \mathrm{B})$ is a key regulator of the transcription of genes that control cellular proliferation

DOI: 10.1677/JME-07-0020 Online version via http://www.endocrinology-journals.org 
and antiapoptosis (Ghosh et al. 1998, Barkett \& Gilmore 1999, Karin \& Ben-Neriah 2000). When bound to an inhibitory protein, $\mathrm{I} \kappa \mathrm{B} \alpha, \mathrm{NF}-\kappa \mathrm{B}$ is present in latent form in the cytoplasm. On activation, degradation of I $\mathrm{B} \alpha$ frees $\mathrm{NF}-\kappa \mathrm{B}$ to enter the nucleus and induce the transcription of target genes (Pahl 1999). During cell apoptosis and proliferation, NF- $\kappa \mathrm{B}$ may have an important role beyond IGF-I-mediated thyroid tissues and cell lines. IGF-I protects neurons (Heck et al. 1999) and lymphocytes (Jimenez Del Rio \& Velez-Pardo 2006) from apoptosis by activating NF- $\kappa \mathrm{B}$. However, the relationship between IGF-I and NF- $\mathrm{BB}$ is not well characterized in normal thyroid lines.

All these observations prompted us to determine if IGF-I influences FLIP expression in thyroid cells by affecting the activity of NF- $\kappa \mathrm{B}$ as a downstream target. We found that IGF-I upregulated FLIP expression in FRTL thyroid cells by means of PI3K-dependent pathway that finally led to the activation of NF- $\mathrm{BB}$.

\section{Materials and methods}

\section{Cell culture and treatment}

FRTL thyroid cells (ATCC catalog number CRTL-1486) were grown in $6 \mathrm{H}$ medium consisting of Coon's modified F12 medium supplemented with $5 \%$ fetal bovine serum and a mixture of six hormones: bovine thyrotropin (1 milliunit/ml), insulin $(10 \mu \mathrm{g} / \mathrm{ml})$, hydrocortisol $(0 \cdot 4 \mathrm{ng} / \mathrm{ml})$, transferrin $(5 \mu \mathrm{g} / \mathrm{ml})$, glycyl-L-histidyl-L-lysine acetate $(10 \mathrm{ng} / \mathrm{ml})$, and somatostatin $(10 \mathrm{ng} / \mathrm{ml})$. Fresh medium was added to all cells every 2 or 3 days and cell passaging was done every 7-10 days. As appropriate for the experiments to be performed, the cells were shifted to $4 \mathrm{H}$ medium containing no thyrotropin, no insulin, and only $0 \cdot 2 \%$ calf serum 2 days before they were used. Then cells were washed twice with PBS. For some experiments, the PI3K inhibitor LY294002 $(10 \mu \mathrm{M})$ or the NF-KB inhibitor BAY11-7082 $(50 \mu \mathrm{M})$ was added $1 \mathrm{~h}$ before IGF-I treatment. Then, IGF-I was added for $24 \mathrm{~h}$.

\section{Real-time PCR}

Total RNA was extracted from cells using a standard Trizol RNA isolation method. Reverse transcription of $1 \mu \mathrm{g}$ RNA was carried out according to the instructions of a commercial Takara RT kit (Takara, Japan). Quality of the RNA and cDNA was checked using DU640 nucleic-acid analyzer (Beckman Coulter, Fullerton, CA, USA). Primers against rat glyceraldehyde-3-phosphate dehydrogenase (GAPDH) were used as an internal control. Following sense and antisense primers were used, respectively: for FLIP, 5'- GCG GTT TGA CCT GCT CAA GA- ${ }^{\prime}$ and $5^{\prime}$-AGC AGC ACC CTA TAA TCG
GAA A- ${ }^{\prime}$, and for GAPDH, $5^{\prime}$-TGG TGG ACC TCA TGG CCT AC-3' and 5'-CAG CAA CTG AGG GCC TCT CT-3'. Real-time PCR was performed with a kit (Quantitect SYBR Green; Qiagen Inc.) by following the manufacturer's instructions. The total reaction volume was $25 \mu \mathrm{l}$, and $100 \mathrm{ng}$ cDNA was used as the template. Fluorescence was detected using a detection system (Prism 7700; ABI, Foster city, CA, USA). PCR products were visualized with gel electrophoresis to confirm a single product of the correct size. Ratios of the target gene to GAPDH were calculated and compared.

\section{Western blotting}

FRTL cells were harvested, centrifuged, and washed with PBS. They were lysed for $20 \mathrm{~min}$ on ice in RIPA buffer containing $1 \times$ PBS, $1 \%$ NP- $40,0 \cdot 1 \%$ SDS, $5 \mathrm{mM}$ ethylenediaminetetraacetic acid, $0.5 \%$ sodium deoxycholate, $1 \mathrm{mM}$ sodium orthovanadate, and $1 \mathrm{mM}$ phenylmethylsulfonyl fluoride. Cells were then centrifuged at $12000 \mathrm{~g}$ for $10 \mathrm{~min}$ at $4^{\circ} \mathrm{C}$. The resulting supernatants were collected and frozen at $-80^{\circ} \mathrm{C}$ or used immediately.

Protein concentrations were determined using a protein assay (bicinchoninic acid, BCA; Pierce, Rockford, IL, USA). We heated $40 \mu \mathrm{g}$ of each sample for $30 \mathrm{~min}$ at $60^{\circ} \mathrm{C}$, then analyzed them by performing $10 \%$ SDS-PAGE and by electroblotting them onto nitrocellulose membranes. Membranes were blocked in $5 \%$ non-fat milk for $1 \mathrm{~h}$ and then incubated with the specific primary antibody overnight at $4{ }^{\circ} \mathrm{C}$. Afterward, they were washed and incubated with appropriate horseradish peroxidase-conjugated secondary antibody. Immune complexes were detected using the enhanced chemiluminescent method, and immunoreactive bands were quantified using an imaging system (AlphaImager 2200; Alpha Innotech Corporation, San Leandro, CA, USA). Values were corrected with the absorbency of the internal control (actin).

\section{Electrophoretic mobility shift assay (EMSA)}

Nuclear extracts for EMSA were prepared with nuclear and cytoplasmic extraction reagents (NE-PER; Pierce). The supernatant fraction containing the cytoplasm and the nuclear extract were prepared separately. Protein concentrations were determined using a protein assay (BCA; Pierce). The amount of protein in each lane was constant in each experiment. EMSA was performed using a commercial chemiluminescent kit (Lightshift; Pierce). The NF-KB consensus oligonucleotide probe (5'-AGT TGA GGG GAC TTT CCC AGG C-3') was end-labeled with biotin (Sangon, Shanghai, China). Nuclear extracts (2-3 $\mu \mathrm{l})$ were incubated for $20 \mathrm{~min}$ at room temperature with $50 \mathrm{ng} / \mu \mathrm{l}$ poly (dI.dC; Pierce), $2 \cdot 5 \%$ glycerol, $5 \mathrm{mM}$ 
$\mathrm{MgCl}_{2}, 0.05 \%$ NP-40, and $50 \mathrm{fmol}$ biotin-labeled NF- $\mathrm{B}$ oligonucleotide probe. Then, $5 \mu \mathrm{l}$ of $5 \times$ binding buffer was added to each $20 \mu$ l binding reaction.

The reaction mixture was subjected to nondenaturing $5 \%$ PAGE in $0.5 \times$ tris-borate-EDTA (TBE) buffer and electroblotted onto a positively charged nylon membrane. After cross-linking with u.v. light, the membrane was blocked, washed, and incubated with a substrate working solution (Lightshift; Pierce). Finally, the membrane was exposed to X-ray film for 2-5 min. Optical density was assessed with the use of a densitometer analysis software (AlphaImager 2200; Alpha Innotech Corporation). Binding reactions with a 200 -fold excess of

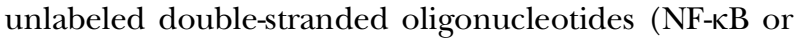
Sp1) were processed as described above and used as controls for binding specificity.

\section{Data analysis}

All experiments were repeated at least thrice. Values are given as the mean \pm s.D. Data were analyzed using SPSS 10.0 software (SPSS, Chicago, IL, USA). Statistical significance was assessed by performing unpaired Student' $t$ test. $P<0.05$ indicated a statistically significant difference.

A

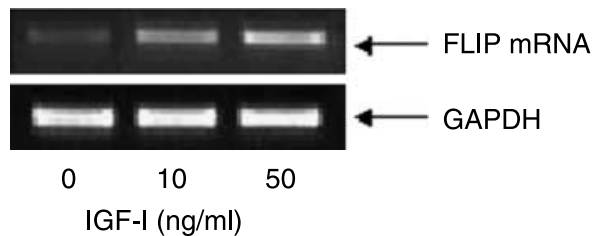

B

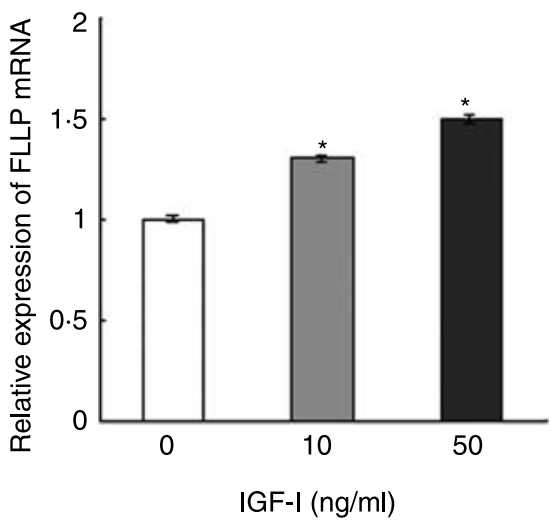

\section{Results}

\section{IGF-I upregulates gene and protein expression of FLIP in a dose-dependent manner}

We first determined whether IGF-I regulated FLIP gene expression in FRTL cells. Results of the reversetranscription PCR showed that IGF-I increased FLIP mRNA levels compared with levels in control cells not treated with IGF-I (Fig. 1A). When we validated this change with real-time PCR, a quantitative method with high-sensitivity, FLIP mRNA levels increased by $30 \%$ with $10 \mathrm{ng} / \mathrm{ml}$ IGF-I and $50 \%$ with $50 \mathrm{ng} / \mathrm{ml}$ compared with controls (Fig. 1B). This indicated IGF-I upregulated FLIP gene expression in a dose-dependent manner. Western blots also showed that IGF-I stimulated FLIP protein expression in a dose-dependant manner (Fig. 1C and D). All indicated IGF-I enhanced FLIP mRNA and protein expression in FRTL cells.

\section{PI3K is involved in the IGF-I-induced increase in FLIP expression}

When we used LY294002, a widespread pharmacological inhibitor of PI3K, to ascertain whether PI3K was involved in the regulation of IGF-I on FLIP,

C

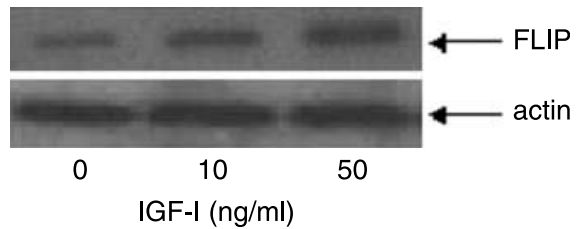

D

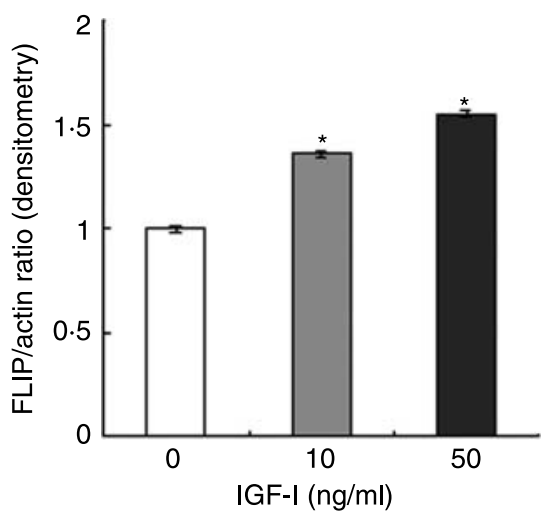

Figure 1 IGF-I stimulates FLIP mRNA and protein expression in a dose-dependant manner. Starved FRTL cells were treated with various concentrations of IGF-I for $24 \mathrm{~h}$ and harvested for analysis. (A) Representative reverse-transcription PCR results. (B) Histogram of real-time PCR results. (C) Cells were treated with 10 or $50 \mathrm{ng} / \mathrm{ml} \mathrm{IGF-I} \mathrm{for} 24 \mathrm{~h}$, washed with phosphate-buffered saline, and lysed. For each sample, $40 \mu \mathrm{g}$ protein was used for western blotting. $\beta$-Actin served as a control to determine equal protein loading. (D) Densitometric results from three experiments of Western blotting. ${ }^{*} P<0.05$ versus untreated group. GAPDH, glyceraldehyde-3-phosphate dehydrogenase. 
reverse-transcription and real-time PCR showed that LY294002 pretreatment decreased the IGF-I-induced FLIP mRNA content to $70 \%$ of that observed in cells treated with IGF-I alone $(P<0 \cdot 05$; Fig. $2 \mathrm{~A}$ and $\mathrm{B})$. This reduction was paralleled by a significant decrease in FLIP protein level $(P<0 \cdot 05$; Fig. 2C and D), which suggested that IGF-I induced FLIP expression depending on PI3K activity in FRTL cells.

\section{IGF-I decreases expression of inhibitory I $\mathrm{B} \alpha$ protein}

Activation of NF- $\kappa \mathrm{B}$ depends on the degradation of its inhibitory protein I $\mathrm{I} B \alpha$. When we measured I $\mathrm{B} \alpha$ protein levels in the cytoplasm using specific anti-IкB $\alpha$ antibody, results suggested that $\mathrm{I} \kappa \mathrm{B} \alpha$ protein expression decreased by about $80 \%$ in FRTL cells treated with IGF-I for $24 \mathrm{~h}$ compared with untreated cells $(P<0 \cdot 05$; Fig. 3$)$. Pretreatment with PI3K inhibitor LY294002 diminished IGF-I-induced degradation of $\mathrm{I} \kappa \mathrm{B} \alpha$, indicating IGF-I induced $\mathrm{I} \kappa \mathrm{B} \alpha$ degradation in the cytoplastic fraction by activating PI3K.

\section{IGF-I activates binding activity of NF- $\kappa B$ DNA through PI3K pathway}

The action of NF-KB in regulating target genes is based on its DNA-binding activity. To assess whether IGF-I has any effect on NF-KB DNA-binding activity, EMSA was performed. Results showed that treatment with IGF-I resulted in strong NF- $\kappa B$-specific gelretarded bands in nuclear samples extracted from FRTL cells relative to untreated cells (Fig. 4, lane 2).
To investigate whether PI3K is also involved in increased NF-КB-DNA-binding activity stimulated by IGF-I, PI3K inhibitor were added, and faint gelretarded bands were found in the nuclear extracts (Fig. 4, lane 3), indicating involvement of PI3K in the

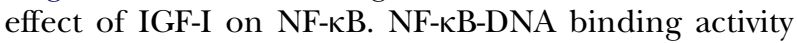
was specific because the band disappeared with an excess of unlabeled NF- $\mathrm{KB}$ oligonucleotides (Fig. 4, lane 4) or with only free labeled probe (Fig. 4, lane 6) but not with Sp1 oligonucleotides (Fig. 4, lane 5). Taken together, these above results indicated that IGF-I/PI3K-mediated degradation of $\mathrm{I} \kappa \mathrm{B} \alpha$ resulted in the translocation of activated NF- $\kappa \mathrm{B}$ into the nucleus to facilitate the binding of NF- $\kappa \mathrm{B}$ with the target gene.

\section{FLIP expression depends on a signaling pathway involving IGF-I, PI3K, and NF-KB}

To further confirm the effect of NF- $\kappa \mathrm{B}$ on FLIP expression, FRTL cells were exposed to NF- $\kappa \mathrm{B}$ specific inhibitor, BAY11-7082. Treatment of FRTL cells with BAY11-7082 markedly decreased IGF-I-induced FLIP expression (Fig. 5). Inhibition of NF- $\kappa$ B by BAY11-7082 combined with inactivation of PI3K by LY294002 decreased IGF-I-induced FLIP protein expression (Fig. 5A, lane 5) more than the decrease caused by inhibiting NF- $\mathrm{KB}$ or PI3K alone (Fig. 5A, lanes 3 and 4). Semiquantitative analysis showed that FLIP protein levels decreased $30 \%$ with PI3K inhibitor, $40 \%$ with NF$\kappa \mathrm{B}$ inhibitor, and $80 \%$ with both inhibitors, compared with cells treated with only IGF-I (Fig. 5B).
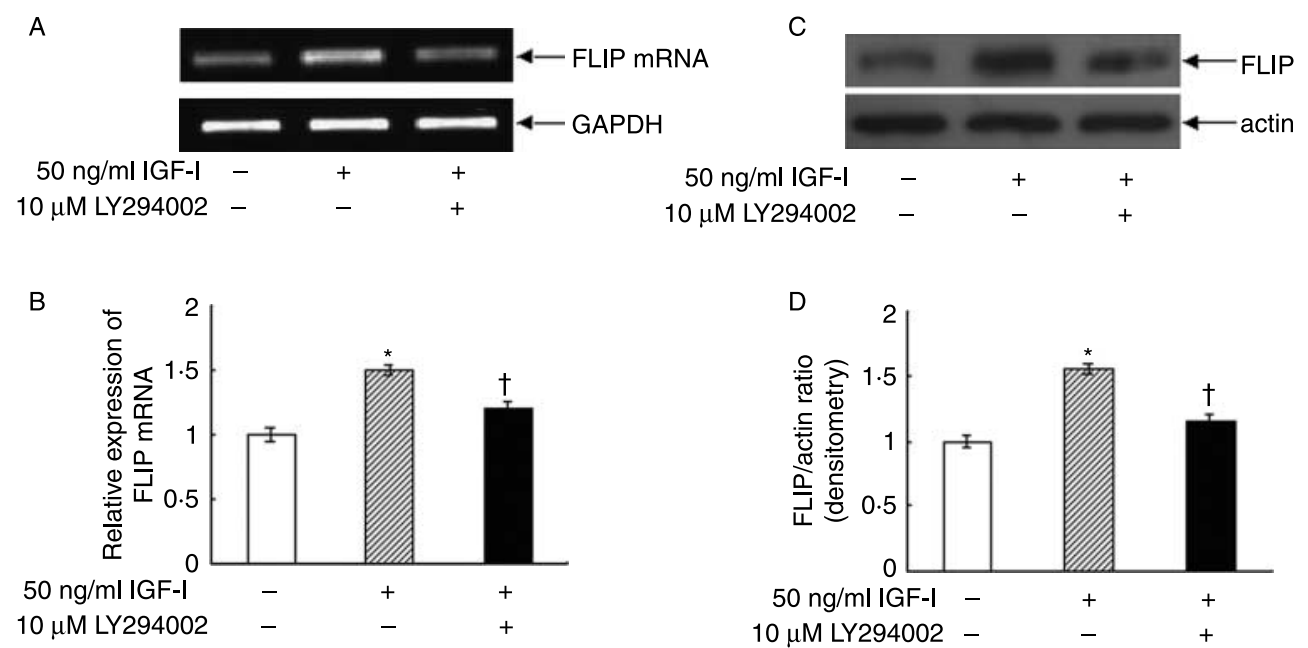

Figure 2 Effect of PI3K inhibitor LY294002 on IGF-I-induced FLIP mRNA and protein expression. Starved cells were preincubated with $50 \mathrm{ng} / \mathrm{ml} \mathrm{IGF-I} \mathrm{for} 24 \mathrm{~h}$ with or without LY294002 (10 $\mu \mathrm{M})$. Reverse transcription (A) and real-time (B) PCR were performed with RNA from FRTL cells. Results from three independent experiments are shown. (C) Equal amounts of total protein were loaded and western blotting was performed to measure FLIP protein expression. A representative blot is shown. (D) Densitometric results from three experiments. ${ }^{*} P<0.05$ versus untreated group. ${ }^{\dagger} P<0.05$ versus IGF-I-treated group. 


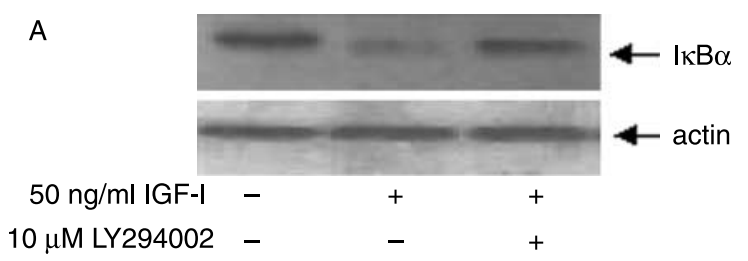

B

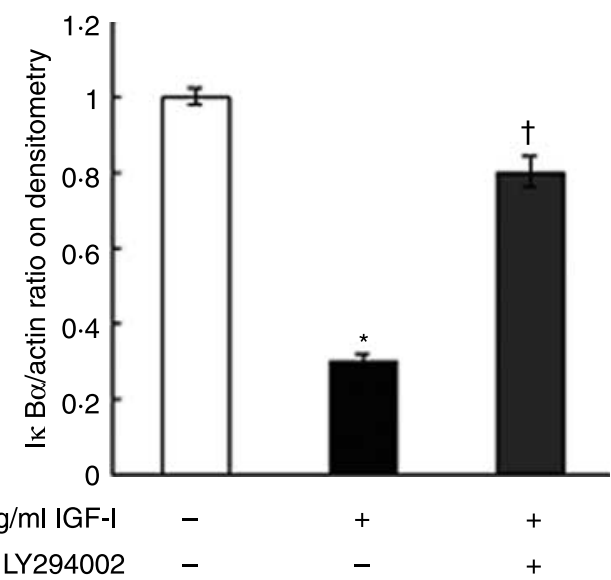

$10 \mu \mathrm{M}$ LY294002

Figure 3 IGF-I decreases the level of inhibitory $I_{\kappa} \mathrm{B} \alpha$ protein by means of PI3K. Starved cells were pretreated with $10 \mu \mathrm{M}$ LY294002 for $1 \mathrm{~h}$ then $50 \mathrm{mg} / \mathrm{ml} \mathrm{IGF-I} \mathrm{for} 24 \mathrm{~h}$. Their cytoplasmic portions were extracted, and protein levels of $I_{\kappa} B \alpha$ were measured on western blots. Equal amounts of protein were loaded to allow direct comparisons. $\beta$-Actin was the loading control. (A) Representative western blot. (B) Densitometric results from three independent experiments. ${ }^{\star} P<0.05$ versus untreated group. ${ }^{\dagger} P<0.05$ versus IGF-I-treated group.

\section{Discussion}

In the present study, we identified NF-KB, a new target of IGF-I-related actions in FRTL cells. IGF-I stimulated the activation of PI3K, increasing the expression of antiapoptotic protein FLIP, at least partly by enhancing $\mathrm{NF}-\kappa \mathrm{B}$ activity.

Our previous study and others have shown that the size of the thyroid in Graves' disease is closely correlated with the serum content of IGF-I (Lakatos et al. 2000), and with the localized expression of IGF-I in thyroid tissues (Maiorano et al. 1998, Vella et al. 2001). Animal models of thyroid goiter demonstrated that increased expression of IGF-I may contribute to early goiter formation (Phillips et al. 1994). On the other hand, upregulated antiapoptotic moleculars, such as FLIP, were also proved to be involved in thyroid goiter formation through preventing apoptotic destruction of thyroid. Our present observation showed that IGF-I induced a marked increase in both FLIP mRNA and protein content of normal thyroid line, which was consistent with studies of thyroid carcinoma cells that IGF-I induced FLIP expression (Poulaki et al. 2002). Induction of FLIP by IGF-I suggests a new mechanism

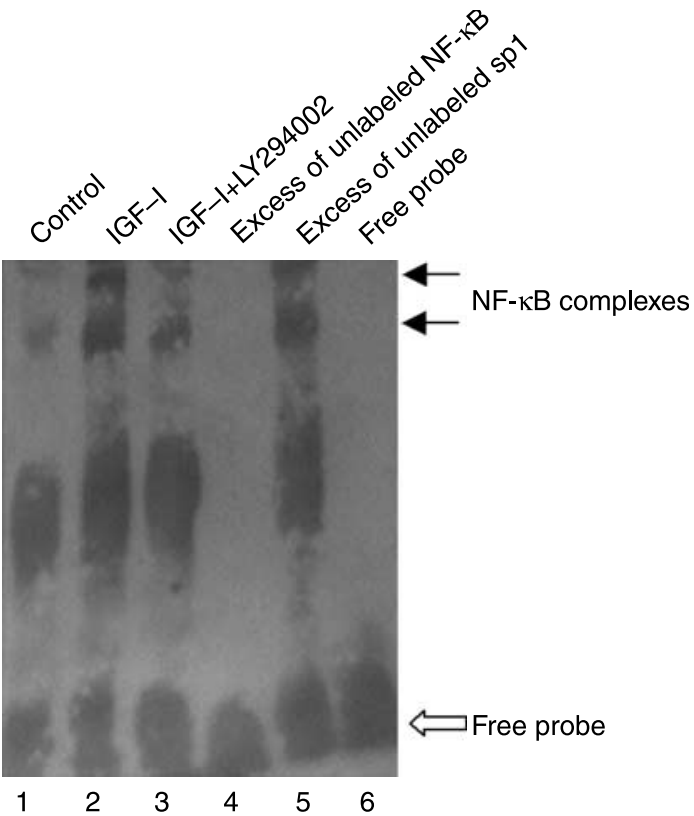

Figure $4 \mathrm{NF}-\kappa \mathrm{B}$ DNA-binding activity in FRTL cells. Equal amounts of nuclear protein extract were prepared from untreated cells (lane 1) and from cells treated with $50 \mathrm{ng} / \mathrm{ml} \mathrm{IGF-I}$ without (lane 2) or with (lane 3) $10 \mu \mathrm{M}$ LY294002. Biotin-labeled $\mathrm{NF}-\kappa \mathrm{B}$ oligonucleotide was used as a probe. Solid and open arrows indicate bands of NF- $\kappa \mathrm{B} / \mathrm{DNA}$ complexes and free probe respectively. Dark bands reflect increased NF- $\mathrm{B}$ DNA binding activity. Specificity of the NF- $\kappa B$ complex was confirmed in competition experiments performed with the same nuclear extracts incubated with an excess of unlabeled NF-KB (lane 4) or Sp1 (lane 5) oligonucleotides; these oligonucleotides eliminated binding and had no effect on binding respectively. Lane 6 is the negative control with only labeled free probe. Similar results were obtained from several experiments.

by which IGF-I and FLIP may contribute to thyroid goiter. Although some attention has focused on the effect of IGF-I on FLIP expression, little information is available about its signaling pathway in normal thyroid tissue and in cell lines.

Evidence from several cell lines indicates that specific tyrosine kinase receptors, such as PI3K, mediate the actions of IGF-I (Withers \& White 2000, Lessmann et al. 2006). Although a previous study showed that PI3K did not affect FLIP expression (Osaki et al. 2004), some antiapoptotic proteins (such as FLIP, survivin, and X-linked mammalian inhibitor of apoptosis protein (XIAP)) were recently identified as substrates for PI3K (Kim et al. 2004, Alladina et al. 2005). Peruzzi et al. (1999) reported that IGF-I-mediated, mitogen-activated protein kinase-dependent survival signals may predominate only when the PI3K pathway is disabled, implicating PI3K as a key regulator in the actions of IGF-I. Our results showed that under the stimulation of IGF-I, inhibition of PI3K activity resulted in reduced mRNA and protein expression for FLIP, which suggests that PI3K is involved in the IGF-I/FLIP signaling pathway. 


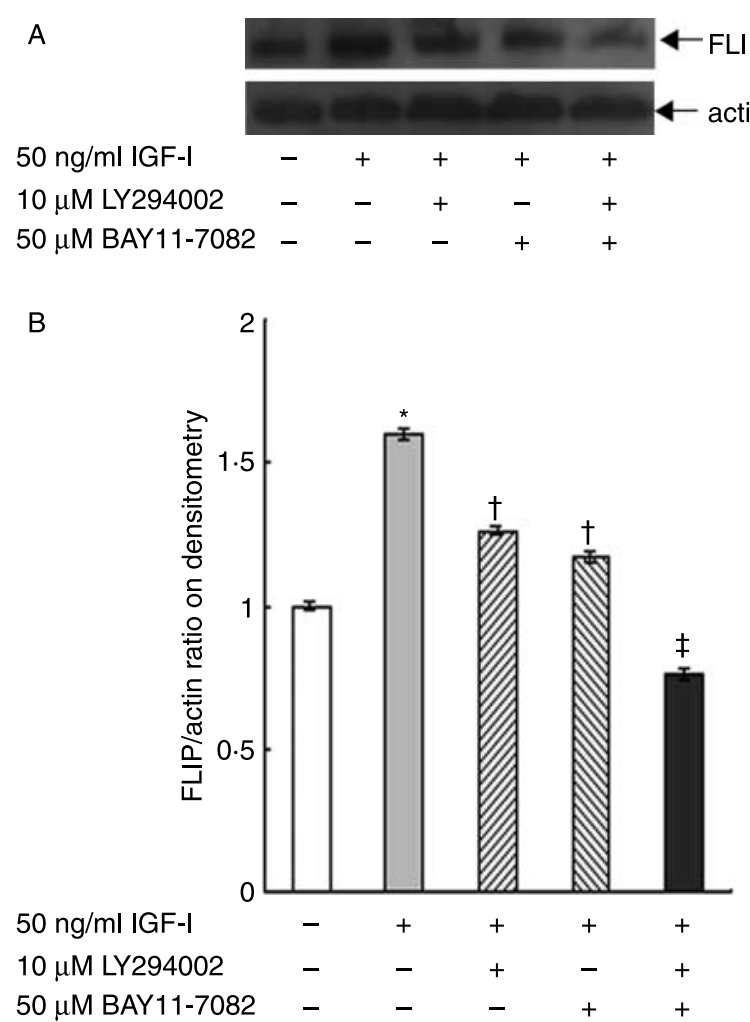

Figure 5 Effect of NF- $\kappa$ B inhibitor BAY11-7082 on protein levels of FLIP. Cells were starved for $48 \mathrm{~h}$. LY294002 $(10 \mu \mathrm{M})$ and/or BAY11-7082 $(50 \mu \mathrm{M})$ were added $1 \mathrm{~h}$ before treatment with $50 \mathrm{ng} / \mathrm{ml}$ IGF-I for $24 \mathrm{~h}$. Western blotting was performed to measure protein levels of FLIP. Equal amounts of protein were loaded to allow direct comparisons. $\beta$-Actin was the loading control. (A) Representative blot. (B) Densitometric results from three experiments. ${ }^{\star} P<0.05$ versus untreated group. ${ }^{\dagger} P<0.05$ versus IGF-I-treated group. ${ }^{\ddagger} P<0.05$ versus group treated with IGF-I and one inhibitor.

NF- $\kappa \mathrm{B}$ is one of the most critical transcription factors involved in the control of cellular proliferation and apoptosis. The effect of IGF-I on NF-KB has recently garnered interest but results still remained controversial. Our confirming experiment demonstrated that the amount of $\mathrm{I} \kappa \mathrm{B} \alpha$ decreased when FRTL cells were stimulated with IGF-I, with a corresponding enhancement of NF- $\kappa$ B DNA-binding activity in the nuclei. In addition, concomitant upregulation of FLIP gene transcription occurred. Further results showed that inhibition of NF- $\kappa \mathrm{B}$ activity eliminated the IGF-I-induced increase in FLIP gene transcription and protein levels, to a certain extent. These suggest that IGF-I-induced FLIP expression is at least partly due to the increased NF- $\mathrm{\kappa B}-$ mediated transcription of the gene for FLIP.

Since both PI3K and NF-KB were involved in the mediation of FLIP expression induced by IGF-I, we examined whether they played roles through a common pathway. The concept that PI3K activation promoted NF- $\kappa$ B activity (Heck et al. 1999) was recently challenged because studies showed that inhibition of PI3K increased DNA binding of NF- $\mathrm{BB}$ in monocytederived dendritic cells (Aksoy et al. 2005). In addition, insulin-related activation of NF- $\kappa \mathrm{B}$ in mammalian cells did not involve PI3K (Bertrand et al. 1998). Our present results showed that the PI3K inhibitor, LY294002, blocked the IGF-I-induced increase in NF- $\mathrm{BB}-$-mediated DNA-binding activity, with an increase in $\mathrm{I} \kappa \mathrm{B} \alpha$ levels, which indicates NF- $\mathrm{B}$ is a downstream molecular of PI3K pathway. Further confirmation was performed by adding LY294002 and BAY11-7082 together to the cultured cells before treated with IGF-I. More obvious decline in FLIP expression was detected as compared with cells treated with BAY11-7082 only, indicating that these two signal molecules were tightly involved in the course of IGF-I regulating FLIP. Therefore, all these suggest that the effect of IGF-I on FLIP is most likely to involve a PI3K/NF-KB-dependent mechanism.

In conclusion, our results have important implications on understanding the mechanism of IGF-Imediated upregulation of FLIP in FRTL cells. To our knowledge, we are the first to demonstrate that the $\mathrm{PI} 3 \mathrm{~K} / \mathrm{NF}-\kappa \mathrm{B}$ signaling pathway is involved in this mechanism. This involvement may explain why IGF-I plays an important role in the formation of thyroid goiters by upregulating antiapoptotic proteins. Our observation provides valuable therapeutic information. However, potential involvement of other signaling pathways and the precise underlying mechanisms still need further investigation.

\section{Acknowledgements}

This work was supported by grants from the National Natural Science Foundation of China (30672748) and from the Shan Dong Administration of Traditional Chinese Medicine (2005-070). The authors declare that there is no conflict of interest that would prejudice the impartiality of this scientific work.

\section{References}

Aksoy E, Vanden Berghe W, Detienne S, Amraoui Z, Fitzgerald KA, Haegeman G, Goldman M \& Willems F 2005 Inhibition of phosphoinositide 3-kinase enhances TRIF-dependent NF- $\mathrm{B}$ activation and IFN-beta synthesis downstream of Toll-like receptor 3 and 4. European Journal of Immunology 35 2200-2209.

Alladina SJ, Song JH, Davidge ST, Hao C \& Easton AS 2005 TRAILinduced apoptosis in human vascular endothelium is regulated by phosphatidylinositol 3-kinase/Akt through the short form of cellular FLIP and Bcl-2. Journal of Vascular Research 42 337-347.

Ashkenazi A \& Dixit VM 1998 Death receptors: signaling and modulation. Science 281 1305-1308.

Barkett M \& Gilmore TD 1999 Control of apoptosis by Rel/NF-kB transcription factors. Oncogene 18 6910-6924. 
Bertrand F, Atfi A, Cadoret A, L'Allemain G, Robin H, Lascols O, Capeau J \& Cherqui G 1998 A role for nuclear factor $\kappa B$ in the antiapoptotic function of insulin. Journal of Biological Chemistry 273 2931-2938.

Ghosh S, May MJ \& Kopp EB 1998 NF-кB and rel proteins: evolutionarily conserved mediators of immune responses. Annual Review of Immunology 16 225-260.

Heck S, Lezoualc'h F, Engert S \& Behl C 1999 Insulin-like growth factor-1-mediated neuroprotection against oxidative stress is associated with activation of nuclear factor $\kappa \mathrm{B}$. Journal of Biological Chemistry 274 9828-9835.

Irmler M, Thome M, Hahne M, Schneider P, Hofmann K, Steiner V, Bodmer JL, Schroter M, Burns K, Mattmann C et al. 1997 Inhibition of death receptor signals by cellular FLIP. Nature 388 190-195.

Jimenez Del Rio M \& Velez-Pardo C 2006 Insulin-like growth factor-1 prevents $\mathrm{A} \beta(25-35) /\left(\mathrm{H}_{2} \mathrm{O}_{2}\right)$-induced apoptosis in lymphocytes by reciprocal NF- $\kappa \mathrm{B}$ activation and p53 inhibition via PI3K-dependent pathway. Growth Factors 24 67-78.

Karin M \& Ben-Neriah Y 2000 Phosphorylation meets ubiquitination: the control of NF-кB activity. Annual Review of Immunology 18 621-663.

Kim S, Kang J, Qiao J, Thomas RP, Evers BM \& Chung DH 2004 Phosphatidylinositol 3-kinase inhibition down-regulates survivin and facilitates TRAIL-mediated apoptosis in neuroblastomas. Journal of Pediatric Surgery 39 516-521.

Kimura T, Van Keymeulen A, Golstein J, Fusco A, Dumont JE \& Roger PP 2001 Regulation of thyroid cell proliferation by TSH and other factors: a critical evaluation of in vitro models. Endocrine Reviews 22 631-656.

Kofidis T, de Bruin JL, Yamane T, Balsam LB, Lebl DR, Swijnenburg RJ, Tanaka M, Weissman IL \& Robbins RC 2004 Insulin-like growth factor promotes engraftment, differentiation, and functional improvement after transfer of embryonic stem cells for myocardial restoration. Stem Cells 22 1239-1245.

Lakatos P, Foldes J, Nagy Z, Takacs I, Speer G, Horvath C, Mohan S, Baylink DJ \& Stern PH 2000 Serum insulin-like growth factor-I, insulin-like growth factor binding proteins, and bone mineral content in hyperthyroidism. Thyroid 10 417-423.

Lessmann E, Grochowy G, Weingarten L, Giesemann T, Aktories K, Leitges M, Krystal G \& Huber M 2006 Insulin and insulin-like growth factor-1 promote mast cell survival via activation of the phosphatidylinositol-3-kinase pathway. Experimental Hematology 34 $1532-1541$.

Maiorano E, Perlino E, Triggiani VV, Nacchiero M, Giove E \& Ciampolillo A 1998 Insulin-like growth factor-1 and insulin-like growth factor receptor in thyroid tissues of patients with Graves' disease. International Journal of Molecular 2 483-486.

Mitsiades N, Poulaki V, Mitsiades CS, Koutras DA \& Chrousos GP 2001 Apoptosis induced by FasL and TRAIL/Apo2L in the pathogenesis of thyroid diseases. Trends in Endocrinology and Metabolism 12 384-390.
Miyakawa M, Tsushima T, Murakami H, Wakai K, Isozaki O \& Takano K 2003 Increased expression of phosphorylated p70S6 kinase and Akt in papillary thyroid cancer tissues. Endocrine Journal 50 77-83.

Osaki M, Kase S, Adachi K, Takeda A, Hashimoto K \& Ito H 2004 Inhibition of the PI3K-Akt signaling pathway enhances the sensitivity of Fas-mediated apoptosis in human gastric carcinoma cell line, MKN45. Journal of Cancer Research and Clinical Oncology 130 8-14.

Pahl HL 1999 Activators and target genes of Rel/NF-kB transcription factors. Oncogene 18 6853-6866.

Peruzzi F, Prisco M, Dews M, Salomoni P, Grassilli E, Romano G, Calabretta B \& Baserga R 1999 Multiple signaling pathways of the insulin-like growth factor 1 receptor in protection from apoptosis. Molecular and Cellular Biology 19 7203-7215.

Phillips ID, Becks GP, Logan A, Wang JF, Smith C \& Hill DJ 1994 Altered expression of insulin-like growth factor-I (IGF-I) and IGF binding proteins during rat thyroid hyperplasia and involution. Growth Factors 10 207-222.

Poulaki V, Mitsiades CS, Kotoula V, Tseleni-Balafouta S, Ashkenazi A, Koutras DA \& Mitsiades N 2002 Regulation of Apo2L/tumor necrosis factor-related apoptosis-inducing ligand-induced apoptosis in thyroid carcinoma cells. American Journal of Pathology 161 643654.

Radcliff K, Tang TB, Lim J, Zhang Z, Abedin M, Demer LL \& Tintut Y 2005 Insulin-like growth factor-I regulates proliferation and osteoblastic differentiation of calcifying vascular cells via extracellular signal-regulated protein kinase and phosphatidylinositol 3-kinase pathways. Circulation Research 96 398-400.

Saito J, Kohn AD, Roth RA, Noguchi Y, Tatsumo I, Hirai A, Suzuki K, Kohn LD, Saji M \& Ringel MD 2001 Regulation of FRTL-5 thyroid cell growth by phosphatidylinositol $(\mathrm{OH}) 3$ kinase-dependent Aktmediated signaling. Thyroid 11 339-351.

Vella V, Sciacca L, Pandini G, Mineo R, Squatrito S, Vigneri R \& Belfiore A 2001 The IGF system in thyroid cancer: new concepts. Molecular Pathology 54 121-124.

Withers DJ \& White M 2000 Perspective: the insulin signaling systema common link in the pathogenesis of type 2 diabetes. Endocrinology 141 1917-1921.

Zhong X, Zhao JJ, Gao L, Liang J \& Wang RX 2006 Association of insulin-like growth factor-I and thyroid volumes in patients with Graves'disease. Journal of Shandong University (Health Sciences) 44 138-142.

Received in final form 20 March 2007

Accepted 25 March 2007

Made available online as an Accepted Preprint 30 March 2007 